\title{
Serological evidence of Toxoplasma gondii infection as potential risk for the development of lepromatous leprosy in an endemic area for both neglected tropical diseases in Brazil
}

Luciana Regina Pereira Oliveira', Lívia Mattos Martins', Rebeka da Conceição Souza', Yuri Scheidegger de Castro ${ }^{1}$, Letícia Silva Nascimento ${ }^{1}$, Juliana Azevedo da Silva', Edilbert Pellegrini Nahn Junior ${ }^{2}$, Wilmar Dias da Silva ${ }^{1,3}$ and Alba Lucínia Peixoto-Rangel ${ }^{1 *}$ (iD

\begin{abstract}
Background: Mycobacterium leprae and Toxoplasma gondii infections are both neglected tropical diseases highly prevalent in Brazil. Infection with certain parasite species can significantly alter susceptibility to other important pathogens, and/or influence the development of pathology. Here we investigated the possible influence of $M$. leprae/T. gondii co-parasitism on the manifestation of leprosy and its clinical forms.
\end{abstract}

Methods: Participants $(n=291)$ were recruited in Campos dos Goytacazes city, Rio de Janeiro state, southeast Brazil, from August 2015 to December 2019 and clinically diagnosed for leprosy. Participants were selected based on the presence (patients) or absence (healthy controls) of the leprosy disease. Contacts of patients were also recruited for this study. Serum samples from patients $(n=199)$ with leprosy, contacts $(n=40)$ and healthy controls $(n=52)$ were investigated for levels of IgM and IgG anti-phenolic glycolipid-1 (PGL-1) by ELISA. Additionally, IgG antibody against soluble Toxoplasma antigen (STAg) was measured in sera samples from leprosy patients, contacts and healthy controls for Toxoplasma gondii serology by ELISA. Anti-PGL-1 lgG and IgM levels were compared using one-way ANOVA Kruskal-Wallis or Mann-Whitney, while Spearman test was used to correlate levels of IgG anti-STAg and IgM/ IgG anti-PGL-1 from seropositive and seronegative individuals for T. gondii infection. The risk of T. gondii infection for leprosy disease was assessed using Fisher's test.

Results: Levels of IgM anti-PGL-1 antibodies were significantly higher in multibacillary (MB) patients compared to paucibacillary (PB) patients $(P=0.0068$ ). Higher IgM and IgG levels anti-PGL-1 were detected in patients with the lepromatous forms. The serologic prevalence for T. gondii infection was 74.9\%. We detected increased anti-STAg antibody levels in leprosy patients (79.4\%), reaching 88.8\% within those with lepromatous form of this disease. The leprosy risk increase in T. gondii seropositive individuals was two-fold (odds ratio [OR] $=2.055$; 95\% confidence intervals [95\% Cl]: 1.18-3.51) higher than those seronegative, and considering the lepromatous leprosy risk this increase was even dramatic $(O R=4.33$; 95\% Cl: 1.76-9.69) in T. gondii seropositive individuals. Moreover the leprosy risk in T. gondii seropositive individuals was weakly correlated to the levels of IgG anti-STAg and IgM/lgG anti-PGL-1. (Continued on next page)

\footnotetext{
* Correspondence: alba@uenf.br

${ }^{1}$ Laboratory of Recognition Biology, Center of Biosciences and

Biotechnology, State University of Northern Rio de Janeiro, Campos dos

Goytacazes, RJ, Brazil

Full list of author information is available at the end of the article
}

(c) The Author(s). 2020 Open Access This article is distributed under the terms of the Creative Commons Attribution 4.0 International License (http://creativecommons.org/licenses/by/4.0/), which permits unrestricted use, distribution, and reproduction in any medium, provided you give appropriate credit to the original author(s) and the source, provide a link to the Creative Commons license, and indicate if changes were made. The Creative Commons Public Domain Dedication waiver (http://creativecommons.org/publicdomain/zero/1.0/) applies to the data made available in this article, unless otherwise stated. 
(Continued from previous page)

Conclusions: Altogether, our results suggest that T. gondii infection may exert immunomodulatory properties that influence to the susceptibility of leprosy, mainly on its more severe clinical form. A better understanding of parasite immunomodulation can ultimately contribute to the development of medical applications.

Keywords: Leprosy, Toxoplasmosis, Coinfection, Co-immunomodulation, Immunoglobulins, Immune response

\section{Background}

Leprosy, caused by Mycobacterium leprae, is an infectious disease that affects the skin, peripheral nerves and presents a clinical-pathological spectrum based on the host immune response [1]. By the latest estimates available, leprosy still occurs in Brazil in high levels having been detected around 26875 new cases in 2017 [2]. Concurrent parasitic infections are common among individuals living under poor sanitary conditions in developing countries. Parasites have evoked a wide range of mechanisms to evade and/or manipulate the host's immune response and establish infection [3-6]. An increasing number of evidence shows that co-infection by pathogens might alter susceptibility to other important pathogens, and/or influence vaccine efficacy through their effects on host immune responsiveness. Soil-transmitted helminth infections have been show to play a role in the progression of leprosy to the more severe clinical type and the occurrence of type 2 reaction in Indonesian individuals [7].

In Brazil, depending on the region studied, the prevalence of Toxoplasma gondii infection in adults can range from 50 to $80 \%$ [8]. Epidemiological studies in Campos dos Goytacazes-RJ, Brazil presented a high T. gondii seroprevalence, reaching even $84 \%$ of the low income population [9]. Drinking water has been determined as the main risk factor for $T$. gondii infection for individuals living under poor sanitary conditions in the same studied area [9]. In a previous report, we have shown the immune response against $T$. gondii, in individuals coinfected with Ascaris lumbricoides, was marked by low secreted levels of IL-10, IL-4, IL-5 and TGF- $\beta$ and low levels of IgE against $A$. lumbricoides, compared to groups not infected by $A$. lumbricoides, favoring helminth adaptation in the host, since the specific protective immune response is down-regulated [10]. Coinfected individuals with less severe ocular toxoplasmic lesions were found having elevated levels of IFN- $\gamma$ (Th1) and IL-13 (Th2). Both cytokines may limit T. gondii growth and control the inflammatory response, which would result in better adaptation of $T$. gondii in the host. Thus, it has been proposed that co-evolution may drive parasite products to modulate the host immune response for better adaptation to both parasites [10]. Krahenbuhl et al. [11] demonstrated that previous infection of mice with $T$. gondii provided protection against challenge with $M$. leprae in the footpad of these animals.
Subsequently, it was shown that macrophages obtained from footpad granulomas M. leprae-infected athymic $(n u / n u)$ mice were defective in responding to macrophage activation signals, such as IFN- $\gamma$ [12]. High levels of anti- $T$. gondii antibodies were detected in leprosy patients sera from Pakistan [13]. Lepromatous leprosy and mucosal leshmaniasis, two opposite polar forms of these diseases, were observed in peripheral blood mononuclear cells culture from patients co-infected, which during active leprosy, the $M$. leprae antigens induced suppression of the IFN-y response to Leishmania braziliensis antigen, and this suppression was abolished by IL-10 neutralization. Moreover this suppressive effect was lost after the cure of leprosy and the disappearance of this effect was accompanied by worsening of mucosal leishmaniasis lesions. The results indicated that leprosy induced an IL-10-mediated regulatory response that could have controlled the mucosal leishmaniasis immunopathology, demonstrating that, in the context of this co-infection, the immune response to one pathogen may influence the immune response of the other pathogen and to the clinical course of the infection caused by it [14].

Epidemiological characteristics of leprosy and toxoplasmosis, raise our interest in better understanding the possible influence of $T$. gondii infection on the outcome of $M$. leprae disease, both endemic in Brazil. Because leprosy primarily affects populations living in poverty environments, $T$. gondii infection can commonly be found as comorbidity in leprosy patients. In this paper, we evaluate the influence of $M$. leprae-T. gondii co-parasitism in the manifestation of leprosy and its clinical forms.

\section{Methods \\ Subjects}

Cases and healthy controls were recruited in Campos dos Goytacazes city, Rio de Janeiro state, southeast Brazil $\left(21^{\circ} 45^{\prime} 15^{\prime \prime} \mathrm{S}\right.$ and $\left.41^{\circ} 19^{\prime} 28^{\prime \prime} \mathrm{W}\right)$. One hundred and ninety-nine leprosy patients were selected at the Hansen Health Program from Campos dos Goytacazes Health Secretariat, which is considered a reference center for treatment of this disease. Forty household contacts were also recruited for this study. All participants were clinically diagnosed according to the Brazilian's Ministry of Health Guidelines and patient's diagnosis was complemented with bacilloscopy of suspected tissue lesions. Healthy controls consisted of 52 unrelated individuals recruited from the local blood bank (hemocenter) 
(Table 1). Leprosy patients (LP), household contacts (CT) and healthy control $(\mathrm{HC})$ were from the same geographical area. Leprosy patients were grouped according to the World Health Organization (WHO) classification [15] in multibacillary (MB) or paucibacillary (PB) leprosy and Madrid classification [16] in lepromatous leprosy (LL), dimorph leprosy (DL), indeterminate leprosy (IDL), and tuberculoid leprosy (TL) for the analysis (Table 1). The informed consent (written) was obtained from all participants and the study was approved by the local Medical Ethics Committee (CAEE No. 32510914.7.0000.5244). Sera samples were obtained by centrifugation of fresh whole blood and stored at $-20^{\circ} \mathrm{C}$ until used.

\section{Soluble toxoplasma antigen preparation}

Tachyzoite forms of Toxoplasma gondii parasites RH strain, maintained in female swiss mice, of approximately, 3-4 weeks old were recovered 2-3 days after infection, for soluble Toxoplasma antigen (STAg). The mice were maintained under suitable ethical conditions, in ventilated cages with free access to water and food, in agreement with international recommendations [17]. STAg were prepared as following: mice peritoneal fluid containing $T$. gondii tachyzoit forms were centrifuged at $100 \times g$ for $5 \mathrm{~min}$; the supernatant was centrifuged again at $913 \times g$ for $30 \mathrm{~min}$ at $4{ }^{\circ} \mathrm{C}$. A small quantity of PBS was added to the parasite sediment and an aliquot of this suspension was removed and diluted 1:100 for counting in a Newbauer chamber. Approximately, $2.5 \times 10^{8}$ parasites per milliliter were exposed to six pulses, of $30 \mathrm{~s}$ each, in ice, using ultrasound equipment (Branson-Sonifier 150) and centrifuged at $900 \times g$ for $20 \mathrm{~min}$. The supernatant was transferred to another tube and centrifuged again at $10000 \times g$ for $10 \mathrm{~min}$. Protein concentration in the supernatant (STAg) was determined by Lowry method [18], and the antigen was then stored at $-20^{\circ} \mathrm{C}$ until use.

\section{Phenolic Glycolipid-1 (PGL-1) ELISA}

IgG and IgM anti-PGL-1 antibodies were detected by enzyme-linked immunosorbent assay (ELISA) as previously described by Bazan-Furini [19], with some modifications.
PGL-1 was coated onto high-affinity polystyrene Nunc ${ }^{\mathrm{m}}$ MaxiSorp $^{\text {Tw }}$ flat-bottom 96 well plates (Thermo Scientific, Massachusetts, USA) using $2.0 \mu \mathrm{g} / \mathrm{ml}$ per well in $100 \mu \mathrm{l}$ of $0.1 \mathrm{~mol} / \mathrm{L}$ sodium carbonate/bicarbonate $\mathrm{pH} 9.6$ (i.e. coating buffer) at $4{ }^{\circ} \mathrm{C}$ overnight. After discarding wells content, sera samples from patients, contacts and healthy controls, diluted of 1:100 in $100 \mu \mathrm{l}$ of dilution buffer $(15 \mathrm{mmol} / \mathrm{L}$ Tris $\mathrm{pH} 7.5$ buffer with $0.05 \%$ Tween 20 , containing $5 \%$ bovine serum albumin [BSA]), were added to the wells and incubated for $1 \mathrm{~h}$ at $37^{\circ} \mathrm{C}$. Next, sera were discarded and $100 \mu \mathrm{l}$ of horseradish peroxidase (HRP) conjugated IgG or IgM (Southern Biotech, Alabama, USA) anti-human antibody diluted 1:1000 and 1: 600 , respectively, in dilution buffer, were added and incubated for $1 \mathrm{~h}$ at $37^{\circ} \mathrm{C}$. The plates were washed four times using $200 \mu \mathrm{l}$ of wash buffer $(15 \mathrm{mmol} / \mathrm{L}$ Tris $\mathrm{pH} 7.5$ buffer with $0.05 \%$ Tween 20 ) and then $100 \mu \mathrm{l}$ of a freshly prepared substrate solution $\{28 \mathrm{mmol} / \mathrm{L}$ citric acid, $48 \mathrm{mmol} / \mathrm{L}$ dehydrated sodium phosphate, $1 \mathrm{mg} / \mathrm{ml} \mathrm{ABTS} \mathrm{(2,2-azino-bis} \mathrm{[3-}$ ethylbenz-thiazoline-G-sulfonic acid])\}, and $0.003 \% \mathrm{H}_{2} \mathrm{O}_{2}$ was added for color development. The plates were incubated for $20 \mathrm{~min}$ (IgG) and for $3 \mathrm{~min}$ (IgM). For IgM test, the reaction was stopped with the addition of $100 \mu \mathrm{l}$ of $15 \mathrm{mmol} / \mathrm{L}$ Tris pH 7.5 buffer with $0.05 \%$ Tween 20 , containing $1 \%$ sodium dodecyl sulfate (SDS) and $0.1 \%$ azide. Absorbance was determined at a wavelength of $405 \mathrm{~nm}$ in ELISA microplate reader (VersaMax ${ }^{\mathrm{mm}}$ Tunable Microplate, VWR International, Pensilvânia, USA).

\section{ELISA for detection of anti-soluble toxoplasma antigen (STAg) antibodies}

A 96-well microtiter plates Nunc $^{\mathrm{TM}}$ MaxiSorp $^{\mathrm{TM}}$ ) were coated with $100 \mu \mathrm{l}$ of $0.1 \mathrm{~mol} / \mathrm{L}$ bicarbonate buffer, $\mathrm{pH}$ 9.6, containing STAg $(10 \mu \mathrm{g} / \mathrm{ml})$, for $18-20 \mathrm{~h}$ at $4{ }^{\circ} \mathrm{C}$ as previously described by Carvalho et al. [20], with some modifications. The plates were three times washed with PBST (PBS 1×; 0.05\% Tween 20). Then, $100 \mu$ l of blocking buffer (PBST, 1\% BSA) was added in each well and incubated for $30 \mathrm{~min}$ at $4{ }^{\circ} \mathrm{C}$. The plates were washed three times and samples (including positive and negative controls) were diluted 1:1000 in diluent buffer (PBST;

Table 1 Study population

\begin{tabular}{|c|c|c|c|c|c|}
\hline & Clinical groups (OMS) & Clinical groups (Madrid) & $N$ & Age Mean \pm SD (Range) & $\begin{array}{l}\text { Gender } \\
\text { Female/Male(\%) }\end{array}$ \\
\hline \multirow[t]{4}{*}{ Leprosy } & \multirow[t]{2}{*}{ Multibacillary } & Lepromatous & 70 & $45.4 \pm 18.6(16-91)$ & 19.0/81.0 \\
\hline & & Dimorph & 66 & $50.4 \pm 20.5(6-93)$ & $32.0 / 68.0$ \\
\hline & \multirow[t]{2}{*}{ Paucibacillary } & Indeterminate & 15 & $30.5 \pm 13.3(11-51)$ & $53.0 / 47.0$ \\
\hline & & Tuberculoid & 48 & $42.4 \pm 19.5(13-86)$ & $52.0 / 32.0$ \\
\hline Healthy controls & & & 52 & $34.6 \pm 11.3(21-60)$ & $23.0 / 77.0$ \\
\hline \multirow[t]{2}{*}{ Household contacts } & & & 40 & $46.9 \pm 16.3(9-71)$ & $65.0 / 35.0$ \\
\hline & & & 40 & $(9-71)$ & $65.0 / 35.0$ \\
\hline Total & & & 291 & & \\
\hline
\end{tabular}


$0.5 \%$ BSA) and added $100 \mu$ to the wells in duplicated. The samples were incubated for $1 \mathrm{~h}$ at room temperature. After washing, antibodies IgG HRP antihuman (Southern Biotech, Alabama, USA) were diluted 1:1000 in diluent buffer and $100 \mu \mathrm{l}$ added to each well and incubated for $1 \mathrm{~h}$ at room temperature. The plates were washed and $100 \mu \mathrm{l}$ of a freshly prepared substrate solution $(28 \mathrm{mmol} / \mathrm{L}$ citric acid, $48 \mathrm{mmol} / \mathrm{L}$ dehydrated sodium phosphate, $1 \mathrm{mg} / \mathrm{ml}$ ABTS and $0.003 \% \mathrm{H}_{2} \mathrm{O}_{2}$ ) was added for color development. The reaction was stopped by the addition of $30 \mu \mathrm{l}$ of citric acid $(0.2 \mathrm{~mol} / \mathrm{L})$ and plates read at $405 \mathrm{~nm}$ in a reader (VersaMax ${ }^{\mathrm{TM}}$ Tunable Microplate, VWR International, Pensilvânia, USA).

The cut-off point of the test was calculated by the mean of negative controls plus three times the standard deviation of these samples, where values below or equal the cut-off were considered negative, and values above the cutoff were considered positive.

\section{Statistical analysis}

Serum levels of anti-PGL-1 IgG and IGM antibodies were compared using GraphPad Prism v.6 Software (GraphPad Software, La Jolla, CA), to perform intra and intergroup statistical analyzes applying the KruskalWallis test, followed by Dunn's test (post test) for comparisons among three or more groups. While the MannWhitney test was used for comparison between two groups. Correlation test (Spearman) between levels of IgG anti-STAg and IgM/IgG anti-PGL-1 from seropositive and seronegative individuals for $T$. gondii infection were also done using GraphPad Prism v.6 Software. Risk analyzes were also performed using Prism with contingency tables and Fisher's test application. All analyzes considered significant $P$-values $<0.05$.

\section{Results}

Detection of IgM and IgG anti-PGL-1 in leprosy patients, contacts and healthy controls

Levels of IgM anti-PGL-1 antibodies were significantly higher in multibacillary $(\mathrm{MB})$ patients compared to paucibacillary (PB) patients $(P=0.0068)$ (Fig. 1A). Considering the Madrid classification, lepromatous leprosy (LL) patients had significantly higher IgM levels compared to tuberculoid (TL) $(P=0.0013)$ and dimorph (DL) $(P=$ 0.0013) patients (Fig. 1B). Patients presenting dimorph dimorph (DD) and dimorph lepromatous (DV) were more similar to LL patients, and this last one had significantly higher IgM levels than tuberculoid (TL) and dimorph tuberculoid (DT) patients (Fig. 1C).

Contrary to IgM analysis, IgG anti-PGL-1 antibody levels were not statistically different between $\mathrm{PB}$ and MB patients (Fig. 2A). However, LL patients presented IgG anti-PGL-1 levels increased in relation to DL, TL and CT individuals. Similarly, HC also

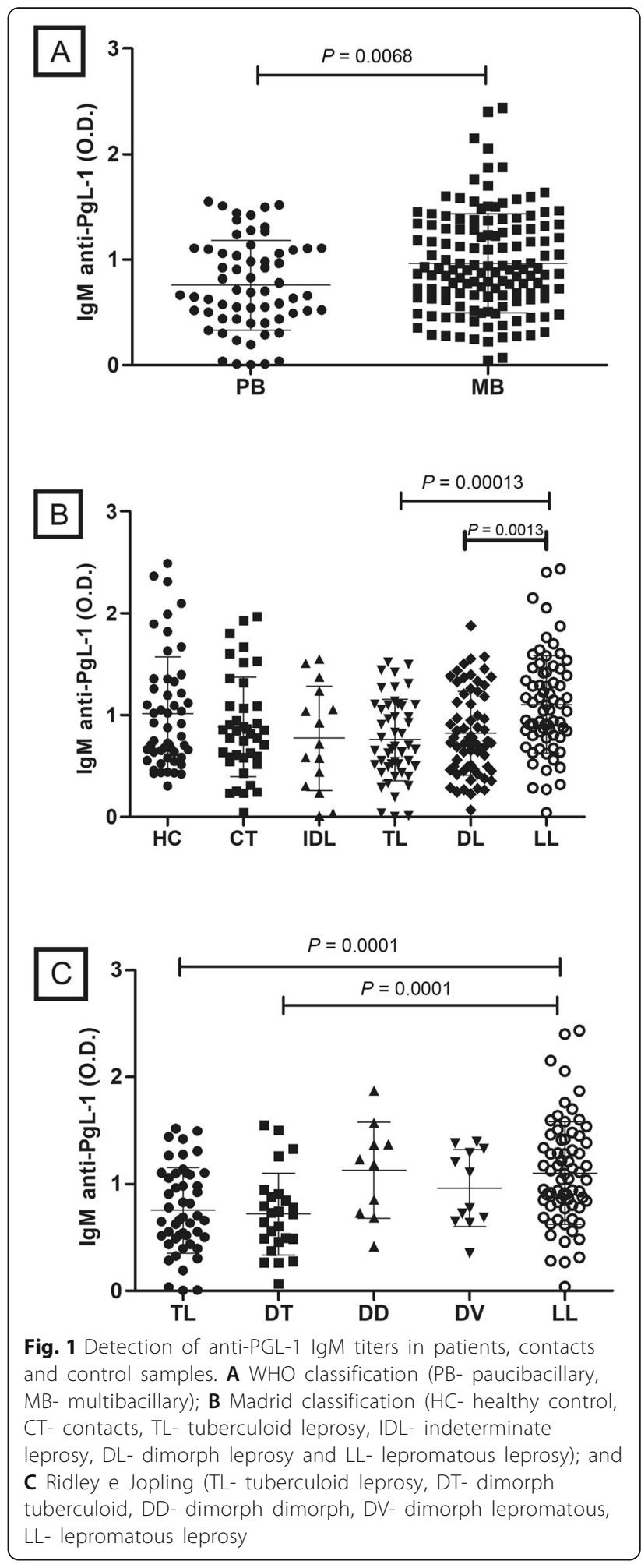

presented higher levels of IgG anti-PGL-1 than CT patients (Fig. 2B). In Fig.2C it is observed increased titers of IgG anti-PGL-1 in LL patients in relation to DT and TL patients. 


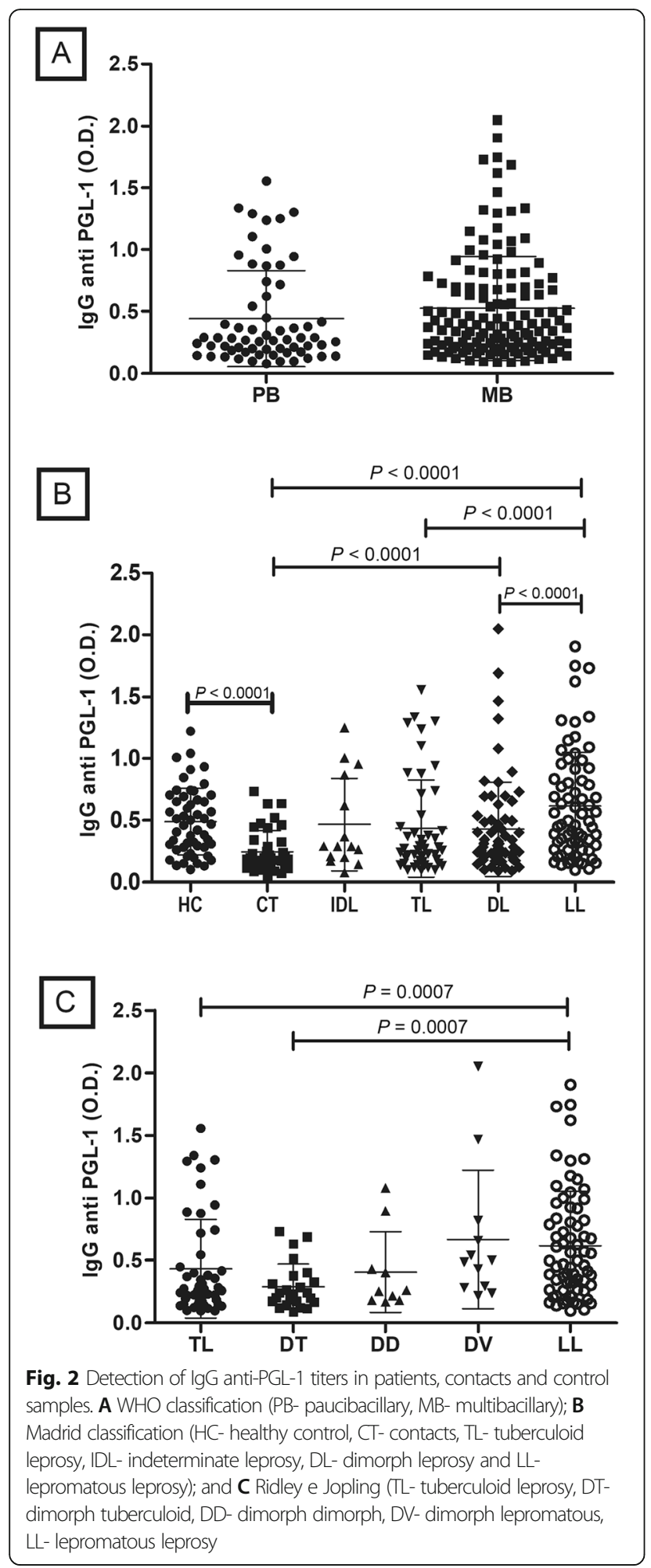

Serological prevalence of $T$. gondii infection in leprosy patients, contacts and healthy controls

IgG anti-STAG was detected in $74.9 \%$ of the studied population. In patients with leprosy, the prevalence of $T$. gondii infection was $79.4 \%$. According to the clinical forms, the serological prevalence of $T$. gondii infection was increased in lepromatous leprosy, reaching $88.6 \%$, compared to the others clinical forms $(70.8 \% \mathrm{TL}, 73.3 \%$ IDL, $77.3 \%$ DL), contacts (60\%) and healthy controls (69.2\%) (Table 2).

\section{Toxoplasma gondii infection as risk factor for leprosy}

Due to the seropositivity for $T$. gondii infection has been increased in lepromatous patients compared to the other clinical forms, Fisher test for risk analyses was conducted in order to verify if $T$. gondii infection would be a risk factor for leprosy development, mainly in its severe form (Table 2). Toxoplasma gondii seropositive individuals had the leprosy risk increased in two-fold (odds ratio $[O R]=2.055 ; 95 \%$ confidence intervals $[95 \%$ $C I$ : $1.18-3.51)$ compared to seronegative. Considering WHO classification, T. gondii infection increased the risk to develop multibacillary (MB) leprosy forms in almost three-fold (OR $=2.620$; 95\% CI: $1.409-4.874)$, compared to paucibacillary forms $(O R=1.263 ; 95 \% C I$ : 0.6355-2.511), which did not present statistical significance (Table 3).

Since $T$. gondii infection has indicated to be a risk factor for MB leprosy development, we assessed if this infection was also a risk factor for leprosy progression to severe clinical forms in Madrid classification. In Table 3 we can see that in deed $T$. gondii infection increase the lepromatous leprosy risk in four-fold $(O R=4.133$; $95 \%$ CI: 1.762-9.694) compared to tuberculoid forms that presented no statistical significance $(O R=1.295 ; 95 \% C I$ : 0.6081-2.759).

Finally, to know whether the risk of $T$. gondii infection was associated to the titers of IgG anti-STAg and IgM/ IgG anti-PGL-1, we performed the correlation analysis from seropositive and seronegative individuals for $T$. gondii infection (Fig. 3). There was a significant positive correlation between the levels of IgG anti-STAg and both IgM/IgG anti-PGL-1 in T. gondii seropositive individuals, but these correlations were weak [IgM ( $r=$ $0.2609) / \operatorname{IgG}(r=0.3026)]$ what may mean that antibody levels are not related to the risk of developing leprosy (Fig. 3A and B). We found no correlation between IgG anti-STAg and IgM/IgG anti-PGL-11 from seronegative individuals for $T$. gondii infection (Fig. $3 \mathrm{C}$ and D).

\section{Discussion}

Here we have suggested that $T$. gondii infection may exert influence on leprosy susceptibility since the leprosy risk increase in $T$. gondii seropositive individuals was two-fold higher than those seronegative, and considering the lepromatous leprosy risk this increase was even dramatic in $T$. gondii seropositive individuals.

Phenolic glicolipid-1 (PGL-1) is the M. leprae-specific antigen [21] and detection of IgM and IgG anti-PGL-1 
Table 2 Serological prevalence for Toxoplasma gondii infection in leprosy patients, contacts and healthy controls

\begin{tabular}{|c|c|c|c|c|c|}
\hline \multirow[t]{2}{*}{ Individuals } & \multicolumn{2}{|c|}{ Classification } & \multirow[t]{2}{*}{$n$} & \multirow[t]{2}{*}{ Positive IgG anti-T.gondii, $n$ (\%) } & \multirow[t]{2}{*}{ Negative IgG anti-T.gondii, $n$ (\% } \\
\hline & $\mathrm{WHO}$ & Madrid & & & \\
\hline \multirow[t]{5}{*}{ Patients } & \multirow[t]{2}{*}{ PB } & Indeterminate & 15 & $11(73.3 \%)$ & $4(26.7 \%)$ \\
\hline & & Tuberculoid & 48 & $34(70.8 \%)$ & $14(29.2 \%)$ \\
\hline & \multirow[t]{3}{*}{ MB } & Dimorph & 66 & $51(77.3 \%)$ & $15(22.7 \%)$ \\
\hline & & Lepromatous & 70 & $62(88.6 \%)$ & $8(11.4 \%)$ \\
\hline & & & 199 & $158(79.4 \%)$ & $41(20.6 \%)$ \\
\hline Controls & & & 52 & $16(30.8 \%)$ & $36(69.2 \%)$ \\
\hline Contacts & & & 40 & $24(60.0 \%)$ & $16(40.0 \%)$ \\
\hline Total & & & 291 & $218(74.9 \%)$ & $73(25.1 \%)$ \\
\hline
\end{tabular}

MB Multibacillary, PB Paucibacillary, IgG Immunoglobulin G

suggest $M$. leprae infection [22]. IgM anti-PGL-1 is detected at higher levels during the long period of infection. However, IgG and IgA anti-PGL-1 specific antibodies can also be detected [23].

Anti-PGL-1 IgM isotype has been used in searching for infection, but not necessarily for the disease, because detectable IgM levels can be found in both infection and disease, although it has been demonstrated that there is a good correlation between the IgM antibody and bacillary load [24], what could explain the levels of IgM to be higher in multibacillary compared to paucibacillary. Moreover, high levels of IgM have also been associated with increased risk for developing leprosy [25]. Although useful in identifying multibacillary (MB) patients, antiPGL-1 antibody levels have little value in detecting paucibacillary (PB) patients, since they develop cellular and non-humoral immunity and therefore often have low or no antibody levels. Antibody levels generally increase as the spectrum from tuberculoid disease (TL) progresses to Lepromatous (LL) form [26, 27]. Interestingly, we observed that IgM anti-PGL1 level is a good marker to distinguish tuberculoids from lepromatous, even within dimorph patients. Our study showed IgM anti-PGL-1 antibody levels significantly higher in $\mathrm{MB}$ patients and lower in PB, while LL patients had higher antibody levels compared to TL and DL patients. Frota et al. [28] and Fabri et al. [29] had also reported higher serum levels of IgM anti-PGL-1 in MB patients compared to those IgM levels observed in PB patients, corroborating our results.

Many studies have shown anti-PGL-1 IgM serology as a tool for early detection of leprosy in household contacts (CT) of patients with the disease $[19,22,30]$. Several studies have reported that high levels of anti-PGL-1 IgM in CT of leprosy patients were related to increased risk of leprosy development [30-32]. Douglas et al. [33] reported that IgM anti-PGL-1 high titers in CT of multibacillary patients had 7.2-fold greater risk of developing leprosy, and 24-fold higher risk to develop multibacillary leprosy compared to anti-PGL-1 IgM seronegative contacts. We also showed anti-PGL-1 IgM levels increased in $\mathrm{CT}$, but also in healthy controls $(\mathrm{HC})$. According to Calado et al. [34], in endemic areas for leprosy, intrahousehold and peridomiciliary contacts, there are no significant differences in seropositivity for anti-PGL-1 IgM.

Table 3 Toxoplasma gondii infection as risk factor for leprosy

\begin{tabular}{|c|c|c|c|c|c|}
\hline & T. gondii positive & T. gondii negative & $O R$ & $95 \% \mathrm{Cl}$ & $P$-value \\
\hline Leprosy & 158 & 41 & 2.055 & $1.186-3.561$ & 0.0131 \\
\hline Not leprosy & 60 & 32 & & & \\
\hline MB & 113 & 23 & 2.620 & $1.409-4.874$ & 0.0026 \\
\hline Not leprosy & 60 & 32 & & & \\
\hline PB & 45 & 19 & 1.263 & $0.6355-2.511$ & 0.6032 \\
\hline Not leprosy & 60 & 32 & & & \\
\hline $\mathrm{LL}$ & 62 & 8 & 4.133 & $1.762-9.694$ & 0.0008 \\
\hline Not leprosy & 60 & 32 & & & \\
\hline $\mathrm{TL}$ & 34 & 14 & 1.295 & $0.6081-2.759$ & 0.572 \\
\hline Not leprosy & 60 & 32 & & & \\
\hline
\end{tabular}

OR Odds ratio, CI Confidence interval, MB Multibacillary, PB Paucibacillary, LL Lepromatous leprosy, TL Tuberculoid leprosy, Fisher's test for risk analyzes 


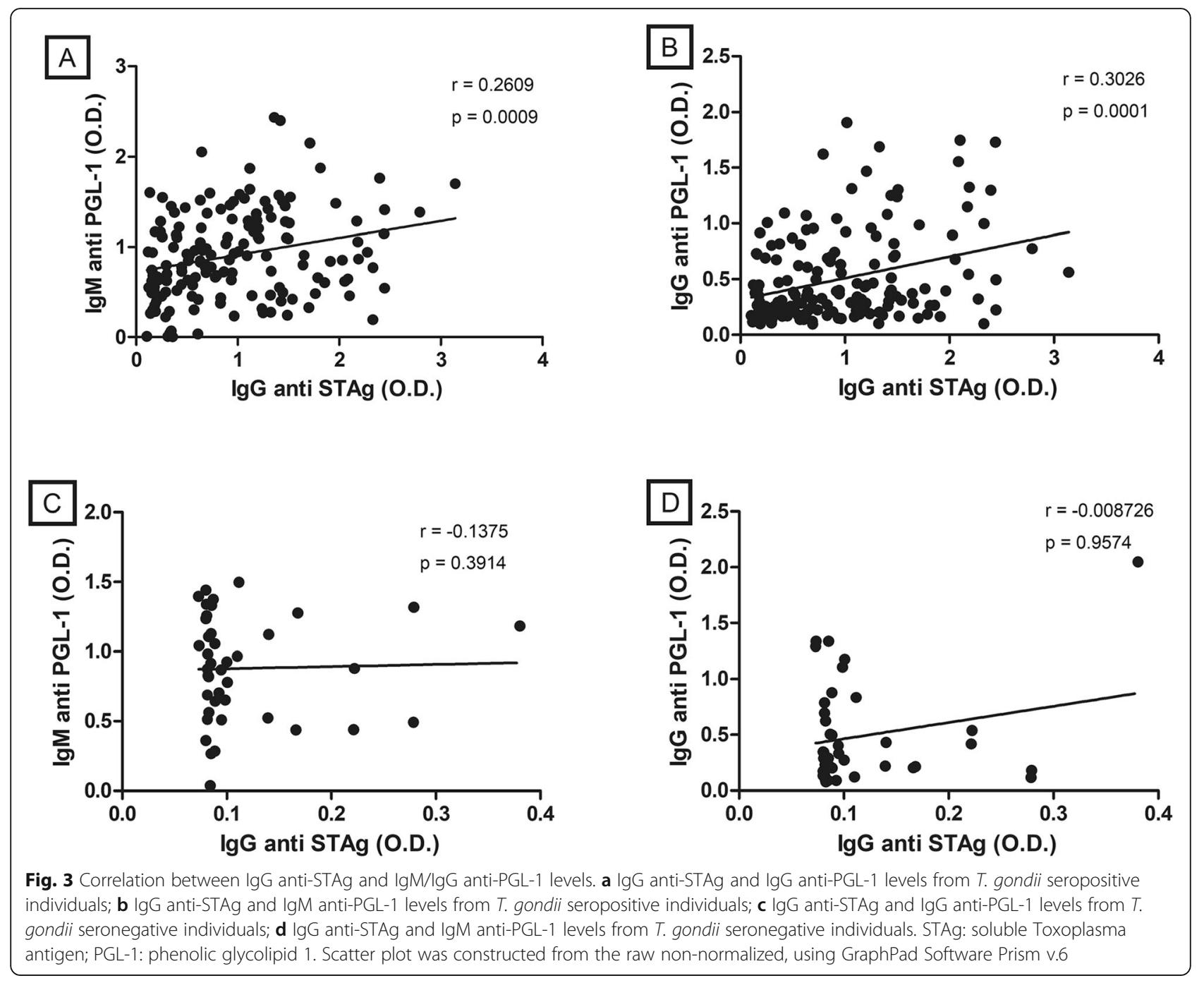

Individuals are commonly exposed to $M$. leprae and develop some degree of immune response, producing antiPGL-1 antibodies [35]. This could explain the high titers of anti-PGL-1 IgM presented in the HC group.

However, not all people exposed to the bacillus who develop anti-PGL-1 antibodies will develop clinical disease [22]. Few serological studies have been performed using anti-PGL-1 IgG [36-39]. The anti-PGL-1 IgM response is uniformly higher than IgG [36]. Several authors have referenced anti-PGL-1 IgM antibody as a parameter for leprosy serology $[29,30,40,41]$. However, it is also possible anti-PGL-1 IgM can be detected in conditions that lead to polyclonal activation of lymphocytes, such as AIDS and psoriasis, even being detected in non-endemic regions [42]. False positives are known to occur in IgM detection due to the presence of rheumatoid factors [39]. In this context, the presence of IgG antibodies in the serum, reflects the safest form of exposure and re-exposure to the bacillus, since these antibodies represent the existence of memory cells at a secondary response moment to $M$. leprae [38]. Cabral et al. [39] observed that IgG levels in controls were lower than in leprosy patients, but did not differ from contacts. It has been proposed that both anti-PGL-1 IgG and IgM isotypes should be measured because of a high frequency of anti-PGL-1 IgM positivity in negative contact samples for anti-PGL-1 IgG. On the other hand, most IgG positive contacts were also positive for IgM antibodies. Healthy controls presented high levels of IgM and IgG, so we can assume that these individuals were exposed to $M$. leprae. Although in our study we found no statistical difference in anti-PGL-1 IgG antibody levels between $\mathrm{MB}$ and $\mathrm{PB}$ patients, it has already been shown, by Brett and colleagues [37], that anti-PGL1 IgG and IgM are higher in LL patients compared to the other leprosy groups. Thus, the results corroborate those in the literature, since LL patients had higher IgG levels compared to other individuals. According to the Ridley and Jopling classification [43] in a previous study, Jadhav et al. [44] also reported lower levels of anti-PGL- 
1 IgG and IgM antibodies in DT patients and higher in LL patients.

Considering leprosy patients, the seroprevalence for $T$. gondii infection increased to $79.4 \%$, and among leprosy patients the highest prevalence for $T$. gondii infection was detected in LL patients, reaching $88.6 \%$. Rao et al. [45] showed a high incidence of Toxoplasma antibody in the lepromatous leprosy group in comparison with control group in an Indian population. These authors supposed this could be related to intimate contact with domestic animals or by ingestion of meat from those animals. A high seroprevalence of $T$. gondii antibodies has also been reported in leishmaniasis caused by either $L$. donovani $(65 \%)$ or L. brasiliensis (16\%) and in Chagas disease (27.9\%) [46]. All these diseases are caused by pathogens which survive and multiply within the macrophage-monocyte system, indicating that there may be a common cause for such a rise in $T$. gondii antibodies in these diseases. Moreover, detection of high titers of anti- $T$. gondii antibodies in sera of patients with leprosy in Pakistan was believed to be induced by an increase in T. gondii load in leprosy due to a transient reactivation of latent $T$. gondii infections, as the antibodies in these leprosy patients were not associated with any sign of eye or lymphatic pathology related to toxoplasmosis [13].

So, we hypothesized $T$. gondii infection as a risk factor for leprosy due to both infectious diseases are associated to poverty conditions and be prevalent in the area of the study. Indeed, seropositivity for T. gondii infection increases at two-fold the risk to develop leprosy, and specially the most severe form, lepromatous leprosy. However, the condition of having or not $T$. gondii infection, seems to be a risk factor for leprosy development instead of the titers of IgG anti-STAg and IgM/ IgG anti-PGL-1. Contrary to our data, BALB/c mice chronically infected with the intracellular protozoan $T$. gondii or Besnoitia jellisoni were resistant to footpad challenge with $M$. leprae. Resistance was manifested by lower numbers of recoverable $M$. leprae in the footpads of protozoal-infected mice and was enhanced in Toxoplasma-infected mice by a booster injection of Toxoplasma antigen in the infected footpad [11]. However, murine is not a good model to study the leprosy infection, since rodents do not systemically develop leprosy disease. There are no studies about immune response modulation in patients co-infected with $M$. leprae and $T$. gondii and the influence of this immunomodulation on the clinical manifestation of leprosy and toxoplasmosis symptoms. These infections have an opposite protection immune response, where toxoplasmosis majority elicits a Th1 cellular immunity, which induces the production of IL-12, IL-2, IFN- $\alpha$ and TFN- $\alpha$ cytokines; while individuals with the most severe form of leprosy (lepromatous) generally develop humoral immune response (Th2 type) with production of IL-4, IL-5, IL-10 and IL-13, which suppress macrophage activities and stimulate mast cell and B lymphocyte activation.

Additionally, our results also suggest a relationship between leprosy and unfavourable economic circumstances, since drinking water has been determined as the main risk factor for $T$. gondii infection for individuals living under poor sanitary conditions in the same studied area [9].

Although further experiments are necessary to confirm the cellular and molecular mechanisms that underpin the effects of $T$. gondii infection on the leprosy manifestation, studies should also consider the order and timing of the infections with two distinct pathogens, since it can significantly influence the host's response to the second.

\section{Conclusions}

$T$. gondii infection could have a certain influence on the progression of leprosy or disease pathogenesis. However, an in-depth immunological study, including cytokine dosage, may add elements to support these preliminary results. Greater understanding of how leprosy progression are influenced by concurrent $T$. gondii infection could help the design of more effective treatments to control the spread of this infectious disease.

\section{Abbreviations}

ABTS: 2,2'-Azino-bis (3-ethylbenzothiazoline-6-sulfonic acid); BSA: Bovine serum albumin; Cl: Confidence Interval; CT: Household contacts; DL: Dimorph leprosy; ELISA: Enzyme-linked immunosorbent assay; HC: Healthy controls; HIV: Human Immunodeficiency Virus; HRP: Horseradish peroxidase; IDL: Indeterminate leprosy; IFN: interferon; IgG: Immunoglobulin G; IgM: Immunoglobulin M; IL: Interleukin; LL: Lepromatous leprosy; LP: Leprosy patients; MB: Multibacillary; OR: Odd ratio; PB: Paucibacillary; PBS: Phosphatebuffered saline; PBST: Phosphate-Buffered Saline Tween; PGL-1: Phenolic glycolipid-1; SDS: Sodium dodecyl sulfate; STAg: Soluble Toxoplasma antigen; TGF: Transforming growth factor; Th: T helper; TL: Tuberculoid leprosy; WHO: World Health Organization

\section{Acknowledgements}

We thank the Hansen Health Program and the Blood Bank (Hemocenter) of Campos dos Goytacazes for assisting with patients at the recruiting facilities. The following reagent was obtained through BEI Resources, NIAID, NIH: Mycobacterium leprae Phenolic glycolipid-I (PGL-I), NR-19342.

\section{Authors' contributions}

LRPO performed the study design and data analyses. LMM performed experimental assays and data analysis. RCS, YSC, LSN performed data collection and analysis; JAS performed in experimental tests; EPNJ performed clinical diagnostics; WDS performed data collection and manuscript preparation; ALPR performed study design, data analysis and manuscript preparation. All authors read and approved the final manuscript.

\section{Funding}

This project has been supported by Foundation Carlos Chagas Filho Research Support of the State of Rio de Janeiro (FAPERJ) - APQ-1 E-26/ $111.196 / 2014$

\section{Availability of data and materials}

The dataset supporting the findings of this article is available from the corresponding author upon request. 


\section{Ethics approval and consent to participate}

The study protocol was approved by The Local Ethic Medical Committee (CAEE No. 32510914.7.0000.5244). Written informed consents were obtained from the participants and/or yours parents/guardians of the participating children.

\section{Consent for publication}

Not applicable.

\section{Competing interests}

The authors declare that they have no competing interests.

\section{Author details}

${ }^{1}$ Laboratory of Recognition Biology, Center of Biosciences and Biotechnology, State University of Northern Rio de Janeiro, Campos dos Goytacazes, RJ, Brazil. ${ }^{2}$ Campos Medical School, Campos dos Goytacazes, RJ Brazil. ${ }^{3}$ Laboratory of Immunochemistry, Butantan Institute, São Paulo, SP, Brazil.

Received: 18 November 2019 Accepted: 3 February 2020

Published online: 13 February 2020

\section{References}

1. Souza C. Hanseníase, formas clínicas e diagnóstico diferencial. Simpósio de Hanseníase. Medicina. Ribeirão Preto. 1997:30:325-34.

2. WHO. Global leprosy update, 2018: moving towards a leprosy free world. In: Weekly epidemiological record. World Health Organization. 2019. https:/apps. who.int/iris/bitstream/handle/10665/326775/WER9435-36-en-fr.pdf?ua=1. Accessed 18 December 2019.

3. Bentwich Z, Kalinkovich A, Weisman Z, Borkov G, Beyers N, Beyers N. Can eradication of helminthic infections change the face of AIDS and tuberculosis? Immunol Today. 1999;20:485-7.

4. Mercadante LM, Santos MASD, Pegas ES, Kadunc BV. Leprosy and American cutaneous leishmaniasis coinfection. An Bras Dermatol. 2018:93(1):123-5.

5. Renz H, Blumer N, Virna S, Sel S, Garn H. The immunological basis of the hygiene hypothesis. Chem Immunol Allergy. 2006;91:30-48

6. Weinstock JV, Elliot DE. Helminths and the IBD hygiene hypothesis. Inflamm Bowel Dis. 2009:15:128-33.

7. Oktaria S, Effendi EH, Indriatmi W, van Hees CL, Thio HB, Sjamsoe-Daili ES. Soil-transmitted helminth infections and leprosy: a cross-sectional study of the association between two major neglected tropical diseases in Indonesia. BMC Infect Dis. 2016;16:258.

8. Bonfioli AA, Orefice F. Toxoplasmosis. Semin Ophthalmol. 2005;20:129-41.

9. Bahia-Oliveira LM, Jones JL, Azevedo-Silva J, Alves CC, Orefice F, Addiss DG Highly endemic, waterborne toxoplasmosis in North Rio de Janeiro state, Brazil. Emerg Infect Dis. 2003;9:55-62.

10. Bahia-Oliveira LM, Silva JA, Peixoto-Rangel AL, Boechat MS, Oliveira AM, Massara CL, et al. Host immune response to Toxoplasma gondii and Ascaris lumbricoides in a highly endemic area: evidence of parasite coimmunomodulation properties influencing the outcome of both infections. Mem Inst Oswaldo Cruz. 2009;104(2):273-80.

11. Krahenbuhl JL, Levy L, Remington JS. Resistance to Mycobacterium leprae in mice infected with Toxoplasma gondii and Besnoitia jellisoni. Infect Immunity. 1974;10:1068-71.

12. Sibley LD, Krahenbuhl JL, Weidner E. Lymphokine activation of J774G8 cells and mouse peritoneal macrophages challenged with Toxoplasma gondii. Infect Immun. 1985;49(3):760-4.

13. Hussain R, Jamil S, Dockrell HM, Chiang TJ, Hasan R. Detection of high titers of Toxoplasma gondii antibodies in sera of patients with leprosy in Pakistan. Trans R Soc Trop Med Hyg. 1992:86(3):259-62.

14. Azeredo-Coutinho RB, Matos DC, Nery JA, Valete-Rosalino CM, Mendonca SC. Interleukin-10-dependent down-regulation of interferon-gamma response to Leishmania by Mycobacterium leprae antigens during the clinical course of a coinfection. Braz J Med Biol Res. 2012:45:632-6.

15. Pardillo FE, Fajardo TT, Abalos RM, Scollard D, Gelber RH. Methods for the classification of leprosy for treatment purposes. Clin Infect Dis. 2007;44:1096-9.

16. Davison AR, Kooij R, Wainwright J. Classification of leprosy. 1. Application of the Madrid classification of various forms of leprosy. Int J Lepr. 1960;28:113-25.

17. Remfry J. Ethical aspects of animal experimentation. In: Tuffery AA, editor. Laboratory animals: an introduction for new experimenters. New York: Wiley; 1987.
18. Lowry OH, Rosebrough NJ, Farr AL, Randall RJ. Protein measurement with the Folin phenol reagent. J Biol Chem. 1951;193:265-75.

19. Bazan-Furini R, Motta ACF, Simão JCL, Tarquínio DC, Marques W Jr, Barbosa $\mathrm{MHN}$, et al. Early detection of leprosy by examination of household contacts, determination of serum anti-PGL-1 antibodies and consanguinity. Mem Inst Oswaldo Cruz. 2011;106(5):536-40.

20. Carvalho FR, Silva DAO, Cunha-Júnior JP, Souza MA, Oliveira TC, Béla SR, et al. Reverse enzyme-linked immunosorbent assay using monoclonal antibodies against SAG1-related sequence, SAG2A, and p97 antigens from Toxoplasma gondii to detect specific immunoglobulin $\mathrm{G}(\mathrm{lgG})$, IgM, and $\lg A$ antibodies in human sera. Clin Vaccine Immunol. 2008;15(8):1265-71.

21. Hunter SW, Brennan PJ. A novel phenolic glycolipid from Mycobacterium leprae possibly involved in immunogenicity and pathogenicity. J Bacteriol. 1981;147(3):728-35.

22. Bührer-Sékula S, Smits HL, Gussenhoven GC, van Leeuwen J, Amador S, Fujiwara T, et al. Simple and fast lateral flow test for classification of leprosy patients and identification of contacts with high risk of developing leprosy. J Clin Microbiol. 2003;41:1991-5.

23. Cruz RCS, Cunha MGS, Vásquez FG. Prevalência de anticorpo anti PGL-1 em contatos domiciliares de pacientes com hanseníase. CadSaude Publica. 2009:17(1):261-71.

24. Lobato J, Costa MP, Reis Ede M, Gonçalves MA, Spencer JS, Brennan PJ, et al. Comparison of three immunological tests for leprosy diagnosis and detection of subclinical infection. Lepr Rev. 2011;82:389-401.

25. Barreto JG, Bisanzio D, Frade MAC, Moraes TMP, Gobbo AR, Guimarães LS, et al. Spatial epidemiology and serologic cohorts increase the early detection of leprosy. BMC Infect Dis. 2015;15:527.

26. Cardoso LP, Dias RF, Freitas AA, Hungria EM, Oliveira RM, Collovati M, et al. Development of a quantitative rapid diagnostic test for multibacillary leprosy using smart phone technology. BMC Infect Dis. 2013;13:497.

27. Richardus RA, van der Zwet K, van Hooij A, Wilson L, Oskam L, Faber R, et al. Longitudinal assessment of anti-PGL-I serology in contacts of leprosy patients in Bangladesh. PLoS Negl Trop Dis. 2017;11(12):e0006083.

28. Frota CC, Freitas MVC, Foss NT, Lima LNC, Rodrigues LC, Barreto ML, et al. Seropositivity to anti-phenolic glycolipid-l in leprosy cases, contacts and no known contacts of leprosy in an endemic and a non-endemic area in Northeast Brazil. Trans R Soc Trop Med Hyg. 2010;104:490-5.

29. Fabri ACOC, Carvalho AP, Araujo S, Goulart LR, Mattos AM, Teixeira HC, et al. Antigen-specific assessment of the immunological status of various groups in a leprosy endemic region. BMC Infect Dis. 2015;15(218):1-9.

30. Cardona-Castro N, Restrepo-Jaramillo S, Gilde La Ossa M, Brennan P. Infection by Mycobacterium leprae of household contacts of lepromatous leprosy patients from a post-elimination leprosy region of Colombia. Mem Inst Oswaldo Cruz. 2005:100:703-7.

31. Goulart IM, Bernardes Souza DO, Marques CR, Pimenta VL, Gonçalves MA, Goulart LR. Risk and protective factors for leprosy development determined by epidemiological surveillance of household contacts. Clin Vaccine Immunol. 2008;15(1):101-5.

32. Penna ML, Penna GO, Iglesias PC, Natal S, Rodrigues LC. Anti-PGL-1 positivity as a risk marker for the development of leprosy among contacts of leprosy cases: systematic review and meta-analysis. PLoS Negl Trop Dis. 2016;10(5), art, no. e0004703.

33. Douglas JT, Cellona RV, Fajardo TT Jr, Abalos RM, Balagon MV, Klatser PR. Prospective study of serological conversion as a risk factor for development of leprosy among household contacts. Clin Diagn Lab Immunol. 2004;11(5): 897-900.

34. Calado KLS, Vieira AG, Durães S, Sékula SB, Oliveira MLW. Positividade sorológica anti PGL-I em contatos domiciliares e peridomiciliares de hanseníase em área urbana. Anais Brasileiros de Dermatol. 2005;80(3):301-6.

35. Barreto JG, Guimarães LS, Leão MR, Ferreira DVG, Lima RAA, Salgado CG. Anti-PGL-1 seroepidemiology in leprosy cases: household contacts and school children from a hyperendemic municipality of the Brazilian Amazon. Lepr Rev. 2011;82(4):358-70.

36. Cho SN, Yanagihara DL, Hunter SW, Gelber RH, Brennan PJ. Serological specificity of phenolic glicolipid I from Mycobacterium leprae and use in serodiagnosis of leprosy. Infect Immunity. 1893;41:1077-83.

37. Brett SJ, Draper P, Payne SN, Rees RJW. Serological activity of a characteristic phenolic glycolipid from Mycobacterium leprae in sera from patients with leprosy and tuberculosis. Clin Exper Immunol. 1983;52:271-9.

38. Nagao-Dias AT, Almeida TL, Oliveira MF, Santos RC, Lima AL, Brasil M. Salivary anti-PGL IgM and IgA titers and serum antibody $\lg G$ titers and 
avidities in leprosy patients and their correlation with time of infection and antigen exposure. Braz J Infect Dis. 2007;11:215-9.

39. Cabral PB, Junior JE, Macedo AC, Alves AR, Goncalves TB, et al. Anti-PGL1 salivary $\mathrm{lgA} / \mathrm{lgM}$, serum $\operatorname{lgG} / \mathrm{lgM}$, and nasal Mycobacterium leprae DNA in individuals with household contact with leprosy. Int J Infect Dis. 2013;17: 1005-10.

40. Moura RS, Calado KL, Oliveira MLW, Bührer-Sékula S. Sorologia da hanseníase utilizando PGL-I: revisão sistemática. Rev Soc Bras Med Trop. 2008:41(2):11-8

41. Zenha EM, Ferreira MA, Foss NT. Use of anti-PGL-1 antibodies to monitor therapy regimes in leprosy patients. Braz J Med Biol Res. 2009;42:968-72.

42. Silva RC, Lyon S, Araos R, Lyon AC, Grossi MAF, Lyon SH, et al. Comportamento dos testes sorológicos ML Flow e ELISA (PGL-1) em áreas endêmica e não endêmica de hanseníase. Rev Soc Bras Med Trop. 2008; 41(2):19-22.

43. Ridley DS, Jopling WH. Classification of leprosy according to immunity. A five-group system. Int J Lepr Other Mycobact Dis. 1966:34:255-73.

44. Jadhav R, Suneetha L, Kamble R, Shinde V, Devi K, Chaduvula MV, et al. Analysis of antibody and cytokine markers for leprosy nerve damage and reactions in the INFIR cohort in India. PLoS Neg Trop Dis. 2011;5(3):e977.

45. Rao KN, Saha K, BhatiaVN GS. Toxoplasma gondii: Antibody in patients of lepromatpus leprosy. J Med Sci Biol. 1989;42:163-8.

46. Franco ELF, Sulzer AJ, Highby RW, Pralta JM. Immunoglobolin G polar staining of Toxoplasma in Fluorescent antibody test. Abstracts of the $10^{\text {th }}$ International Congress on Tropical Medicine and Malaria, Manila; 1980. p. 9-15.

Ready to submit your research? Choose BMC and benefit from:

- fast, convenient online submission

- thorough peer review by experienced researchers in your field

- rapid publication on acceptance

- support for research data, including large and complex data types

- gold Open Access which fosters wider collaboration and increased citations

- maximum visibility for your research: over $100 \mathrm{M}$ website views per year

At $\mathrm{BMC}$, research is always in progress.

Learn more biomedcentral.com/submissions 